\section{Edmondo Malan}

\author{
Giovanni B. Agus \\ Vascular Surgery, University of Milan, \\ Italy
}

\section{An introductory note}

The lack of masters, in all fields, is a major concern in Italy today. Fortunately, we are offered opportunities to explore ideas and read publications that can compensate for this deficiency. I may mention a couple of considerations that have shaped my thought, together with the memory of the two great clinicians: Edmondo Malan and Giorgio Agrifoglio.

In medicine, the process of hyperspecialization of disciplines, with the creation of sub-specialties within the same specialties, has deeply changed the nature of the relationship between the physician's work and the means, the instruments required for the practice (formulation of diagnoses and treatment of patients). Until the 70's, those means were themselves a constituent of the medical profession, and diagnostic and therapeutic skills were acquired with a long learning path that passed through semiotics (from inspection to palpation) and training at the patient's bed under the guidance of a master. Great clinicians were distinguished by their capacity to observe the symptoms and signs of a disease by using traditional semiotic tools - the sole option available at the time: the confirmation of clinical suspicion. The clinical eye was the capacity to correlate the clinical signs observed in the real patient, even when they were minimal or barely perceptible, with specific medical conditions and syndromes. The insight of the master was the result of years of expertise built at the patient bedside, and on autopsy findings when the cause of a death could not be determined. As the founder of Clinical Medicine, Augusto Murri, said: The secret of success in the medical practice is not so much in the acquisition of a huge knowledge, nor in having seen a large number of patients. These are certainly two very useful requirements, but the most essential challenge lies half-way, that is to say in the capacity to apply the acquired notions to each individual case. ${ }^{1}$

But I will draw an even more difficult meaning of the term master from the words of a great artist, Giovanni Testori, who said: A man begins to become our master when he makes us understand that he has travelled all the roads of the world to reach us, and not vice versa. A master is not a sublime service provider, but a man who gives his whole self to us, a totally naked heart for us. A master, indeed, always asks the learner to do what he does not yet know, and not what he already knows. ${ }^{2}$

\section{Edmondo Malan, forty years later}

The birth of angiology and vascular surgery, not only arteries and veins: from kidney transplantation to the focus on vascular malformations

Pilgrimage across universities, once a common custom that enriched the Academy, was a precious practice in the opinion of Professor Malan, who considered it useful to follow trends in the atherosclerotic disease both in time and (geographical) space. His experience in Catania, reviewed several years later, appears to have been extremely significant from the point of view of changes in the disease.

Atherosclerotic arteriopathy was almost non-existent. I only saw diabetic arteriopathies and Buerger's disease. Today it's the opposite. Buerger's disease has almost disappeared; atherosclerotic disease is largely a function of time, and partly of space, meaning that different eating habits and other local factors have an undoubted epidemiological dimension (Malan, 1973). After 11 years, in the early afternoon of a day of April 1949, a line of cars set out from Catania and headed to Messina for the first stretch of Professor Malan's journey towards new academic achievements in equally prestigious locations: Parma, Genoa, Milan.

Edmondo Malan, born in Turin, graduated in 1933. He studied with Uffreduzzi, and followed Dogliotti in Modena and Catania. And it was in the Sicilian city, where he stayed from 1938 to 1949 (with a break of two years spent in war, on the Greek-Albanian front), that he started to take an interest in angiology. He studied Buerger's disease and set out to deliver endoarterial vasodilation treatments with excellent results.

His most significant work is described in Surgical treatment for chronic peripheral obliterating arteriopathies, which Malan published, together with his master Dogliotti, in 145 pages and 24 tables. At that time, presentations were not short summaries or reviews, as we would say now, but original works. ${ }^{3}$

In Parma, thanks to his eclectic nature, he was among the firsts to understand the importance of a specific study of the problems of anesthesia and resuscitation, and reorganized surgery in a team work con-
Correspondence: Giovanni B. Agus, Vascular Surgery, University of Milan, Italy.

E-mail: agus.gb@fastwebnet.it

Key words: Italian Phlebolymphology; history; Masters of the past; phlebology; lymphology.

Conflict of interests: the author declares no potential conflict of interests.

This paper is part of the monographic issue: 'Did the Masters of the past know the future? History and update of Italian Phlebolymphology' - Guest editor: Alberto Macciò (Phlebology - Part I edited by G. Agus; Phlebology - Part II edited by P. Bonadeo; Lymphology edited by F. Boccardo).

Received for publication: 30 June 2020.

Revision received: 10 July 2020.

Accepted for publication: 15 July 2020.

This work is licensed under a Creative Commons Attribution 4.0 License (by-nc 4.0)

COPyright: the Author(s), 2020

Licensee PAGEPress, Italy

Veins and Lymphatics 2020; 9:9250

doi:10.4081/vl.2020.9250

ducted with the Professor of Anesthesiology Rinaldo Trazzi. As a testimony of this new focus on the surgical patient, we are left with his excellent report on the Evaluation of the resistance of the surgical patient (Trieste, 1952) and with Surgery in the elderly.

The need to add instrumental assessment methods to basic clinical medicine for a better hemodynamic balance led him to advocate - together with a South African surgeon, Goetz - for the study of vascular diseases by using a plethysmograph, the equipment that would be called GoetzMalan plethysmograph for many years to come.

But it was certainly in Milan that the most important research and clinical case study results in Europe became known to all, first in the old Zonda pavilion, and since 1967 in the very modern and pioneering Institute of Angiology and Vascular Surgery of the University, in the Mangiagalli pavilion of the glorious Milan medical and academic institution ICP (Istituti Clinici di Perfezionamento). That was the very origin of the young University of Milan, founded by Prof. Mangiagalli, gynecologist of the University of Pavia, and then a Senator and Mayor of Milan.

Kidney transplantation would start to be performed in Milan, but Malan, with great modesty, shared his merits with others when 
he told the press: We are neither among the most advanced nor among the most backward countries. A lot of progress has been made, but much remains to be done. The excellent performance of the Milan, Rome and Verona centers allows us to nourish hope for the near future.

His relations with the élite of the enthusiasts of vascular diseases, and particularly with the French Fontaine and Reboul, and with the Portuguese Dos Santos (Figure 1), spread the news of this tiny group naming them The Four Musketeers of European Vascular Surgery. Their expertise gave life to the European Cardiovascular Society and led to the first international cardiovascular surgery meeting in Turin. ${ }^{4}$ During his academic period in Genoa, two events took place that represented a very significant milestone for the new medical Vascular branch: the creation of the Journal of Cardiovascular Surgery, published in English with the Italian publisher Minerva Medica of Turin (the famous green journal), and the opening of the first Specialization School of Angiology.

Malan, in fact, as we said, was not only interested in surgery. He had vast horizons in medicine, starting from methodology and epidemiology, but always with a special fondness for vascular diseases. In the early 1970 s he was one of the promoters of a wide-ranging debate and work on Angiological nosology. Classification of vascular diseases of the limbs (Florence 1974), which later converged into a document that was published in Italy and globally by Minerva Cardioangiologica and through the Journal of Cardiovascular Surgery - the same that happened many years later with the Consensus Statement by the Anglo-Saxon Consensus Conference.

In vascular epidemiology he played an important role in the field of phlebology with the fundamental epidemiological contribution on Varicose disease of the lower limbs, which was published in the Archives of Mutual Medicine of 1961 (with V. Giabbani) and definitely shed light on the socio-economic importance of chronic phlebopathies.

He had a great interest in phlebology, the Cinderella of medicine. His enthusiastic forward to the work of Glauco Bassi, an eminent phlebologist, was an opportunity for him to call for a dignity and seriousness of commitment that reprimanded, for example, the rampancy of pseudo-scholars, clumsy stingers of veins, even though he was not against a serious and well-executed sclerotherapy. At the Zonda, he called people like the Irish George Fegan to teach, not from the chair but in practice, the modern sclerosis of truncal veins.
As to the unregulated practice of saphenous stripping and regarding the need for accurate diagnostics in phlebology, Malan stated, in an important international symposium in 1970: Nous effectuons le stripping seulement quand nous avons une certitude clinique; dans le doute, nous faisons une phlébographie (there were no Doppler and ultrasound in medicine yet!) Nous estimons que l'indication du stripping doit être posée d'une façon précise, sur la base d'une très bonne anamnèse et d'une recherche cliniques bien suivie.

Another chapter that had a wide international resonance among angiologists and vascular surgeons was that of syndromes derived from arterial-venous anastomosis and the notions on the importance of hemodynamics (Malan syndromes). As another great Master, the French Georges Arnulf, wrote: Je ne peux personnellment qu'attirer l'attention sur la valeur des documents de Malan sur la physio-pathologie des affections vasculaires et tout spécialement sur les fistules et anasomoses artério-veineuses - sans omettre le beau livre - véritable chef d'ouvre sur les malformations vasculaires auxquelles ils ont réservé le nom d'Angiodysplasias (this is the famous red book of the Carlo Erba Foundation). ${ }^{5}$ But already in 1967 Malan's work had been recognized in this difficult area of vascular conditions in the classical treaty of Angiology by Fernando Martorell. ${ }^{6}$

We could continue for a long time also by talking about his attention to every patient, as shown in the beautiful image created by Guido Crepax for him (on Tempo Medico - cover and central article of issue $n$. 113, available at: http://www.aiap.it/cdpg/ ?ID $=7127 \&$ IDsubarea $=169 \&$ IDsez $=225){ }^{7}$ It was that attention to the needs of each individual patient with a peripheral arterial disease that suggested to him to count the meters he could walk before the inevitable cramp due to intermittent claudication - just like the pragmatic North-American suggestion for the patient to count feet when walking around their blocks.

In his teaching activity for the training of the best doctor, he taught: Learning surgery is a challenging task, one that requires great commitment in long hours of study and intense physical work, combined with an unbiased attitude and strong will. These qualities may lead a young man to become a great surgeon, but to be a complete surgeon there is one fundamental trait he should acquire: human understanding. In many cases, the surgical intervention is an act of faith of the patient and surgeon, and it can be well accomplished only through mutual understanding. ${ }^{8}$

Another interest he had, although little known, was that on the influence of climate on the human being and on vascular diseases intended, as they sometimes are, as meteoropathies. He wanted to study this with the meteorological service of the Linate Airport.

We already mentioned his interest in Buerger's disease, but it is worth recalling the malariotherapy he would develop together with Professor Corelli of Rome.

A summary and critical work of all the scientific work carried out by Professor Malan and his School from 1943 to 1978 was given to us in 1983 by his first student Guido Tattoni, head of a Vascular Surgery Division, the first in time and among the best Italian vascular surgeons. ${ }^{9}$

In 1976, another important publication of 330 pages was dedicated to him by his students. ${ }^{10}$

Celebrating the Master through his works and ideas is highly praiseworthy,

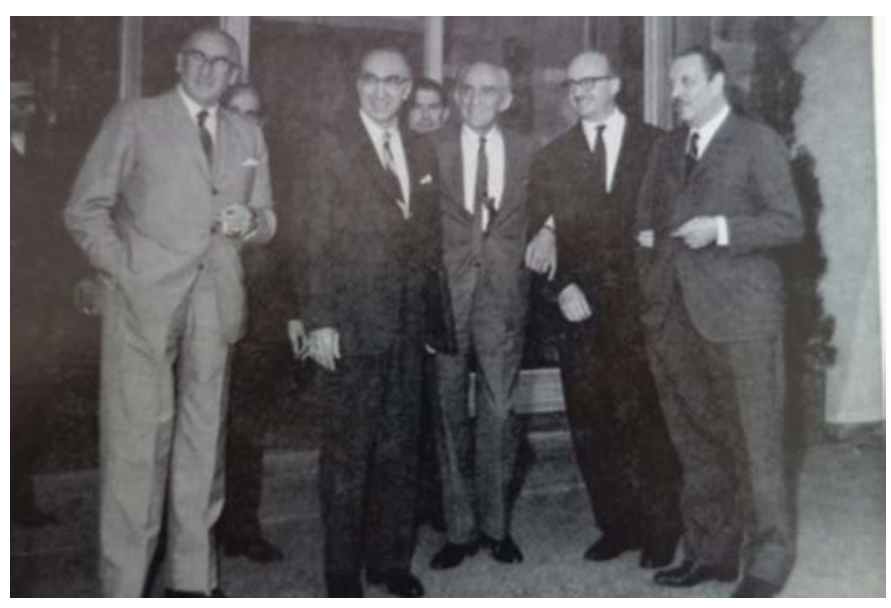

Figure 1. Two of The Four Musketeers of European Vascular Surgery, Malan and Dos Santos on the side, with in the center Michael De Bakey and Achille Mario Dogliotti. 
maintained Giuseppe Zannini when he recalled Edmondo Malan as a bright researcher and clinician, capable of arousing the interest of young people for a field that was opening up to knowledge and looked particularly attractive. One most compelling thing was the way in which Malan approached problems and faced knowledge, as Zannini recalled in describing his work method, always discussed in depth in his conference contributions.

Then we should mention his treaties on vascular surgery, which remained a milestone in learning for a long time. ${ }^{11}$

Another surgeon of a different school, Piero Pietri, twenty years after the passing of Malan - rightly recalled in the Treccani Encyclopedia - ${ }^{12}$ could and would write of him, who had not been his teacher but still a mentor: when one thinks of his masters, the prevailing sentiment is almost always veneration, often regret and nostalgia.

These feelings are even more appropriate today for us, dwarves on the shoulders of giants, in an epoch that can instantaneously erase the memory of experiences where the physician was the real protagonist. In recent historical works, we need to remember Malan, and the other masters of international vascular surgery. ${ }^{13}$

Being the last director of the Institute of Vascular Surgery and Angiology, I witnessed its liquidation 40 years after its founding by Professor Malan and an enlightened hospital president as Mrs. Erisia Gennai Tonietti was, in favor of modern departmentalizations with a single cost center - because today economy prevails over patients, teaching and research, even up to the abolition of university faculties. As we know, today we live in a liquid society and nothing is safe and durable anymore, as Zygmunt Bauman taught us.

These few considerations came to my mind during my descent of the Kilimanjaro on 24 January 2008, exactly thirty years after the death of a Master.

\section{References}

1. Murri A. Quattro lezioni e una perizia. Il problema del metodo in medicina e biologia. Bo-logna: Zanichelli; 1973.

2. Doninelli L. Una gratitudine senza debiti. Giovanni Testori, un maestro. Milano: La nave di Teseo; 2018.

3. Dogliotti AM, Malan E. Terapia chirurgica delle arteriopatie obliteranti periferiche croniche. Archivio e Atti $51^{\circ}$ Congr Società Italiana di Chirurgia. Roma: EMES; 1949.

4. AAVV (presentazione di E. Malan). Atti della prima riunione internazionale di angiocar-diochirurgia. Torino $30 \mathrm{mag}$ gio-1 giugno 1951. Milano: Mellon; 1951.
5. Malan E, ed. Vascular Malformations (Angiodysplasias). Milano: Carlo Erba Foundation; 1974.

6. Martorell F. Angiologia. Enfermedades vasculares. Barcelona: Salvat Ed.: 1967.

7. Tempo Medico, Rivista di attualità per il medico, n. 113. In copertina è ritratto Edmondo Malan, chirurgo. Copertina di Guido Crepax. Editrice Pierrel S.p.a; 1973.

8. Malan E. In: V. Ghetti (a cura di), Guida CIBA per il Giovane Medico. Milano: CIBA; 1969.

9. Tattoni G. La Scuola del Prof. E. Malan e le malattie vascolari periferiche. Maniago (PD): Off Grafiche LEMA; 1983.

10. AAVV. Scritti degli Allievi in onore del Prof. Edmondo Malan nel $26^{\circ}$ anno del suo ordi-nariato. Osnago (CO): Off Grafica Morell; 1976.

11. Malan E. Trattato di Tecnica Chirurgica. Chirurgia Vascolare. Torino: UTET; 1980.

12. Franchini AF. Edmondo Malan Dizionario Biografico degli Italiani. Roma: Treccani; 2007.

13. Chiesa R, Melissano G, Setacci C, Argentieri A. History of aortic surgery in the world. To-rino: Ed. Minerva Medica; 2015. 